\title{
Fatty acids Composition, Antimicrobial Potential and Cosmeceutical Utilization of Prosopis africana Seed Oil
}

Marili Funmilayo ZUBAIR*1/2, Olubunmi ATOLANI ${ }^{3}$, Sulyman Olalekan IBRAHIM ${ }^{1}$, Olubunmi Stephen OGUNTOYE ${ }^{3}$, Rukayat Abiodun OYEGOKE ${ }^{4}$, Gabriel Ademola OLATUNJI ${ }^{1}$

${ }^{1}$ Department of Industrial Chemistry, University of Ilorin, P.M.B. 1515, Ilorin, Nigeria.

${ }^{2}$ Department of Chemistry, Kwara State University, P.M.B. 1530, Malete, Nigeria.

${ }^{3}$ Department of Chemistry, University of Ilorin, P.M.B. 1515, Ilorin, Nigeria.

${ }^{4}$ Department of Biohemistry, University of Ilorin, P.M.B. 1515, Ilorin, Nigeria.

* Corresponding author: e-mail: marilizub@unilorin.edu.ng; Tel: +2348030661412

Received December 25 th $^{\text {2017; } \text { Accepted March 20 }}{ }^{\text {th }}, 2018$.

DOI: http://dx.doi.org/10.29356/jmcs.v62i3.435

\begin{abstract}
The physicochemical properties, fatty acids profile, antimicrobial activity and soap potential of the seed oil of Prosopis africana were examined. The prepared natural antiseptic soap was absolutely devoid of all forms of synthetics such as alkaline, antimicrobial agents, preservatives, colourants and fragrances. The seed had an oil yield of $4.98 \%$ while the saponification, acid, free fatty-acids and iodine values were found to be $11.60 \pm 0.54 \mathrm{mgKOH} / \mathrm{g}, 16.96 \pm 0.57 \mathrm{mgKOH} / \mathrm{g}, 14.60 \pm 0.45 \%$ oleic and $145.47 \pm 0.66 \mathrm{I}_{2} 100 \mathrm{~g}^{-1}$ of the oil respectively. The GC-MS result of the prepared fatty acid methyl ester (FAMEs) indicated the presence of oleic acid (33.67\%), a monounsaturated fatty acid as the most prominent fatty acid in the oil, followed linoleic acid (18:2), a polyunsaturated acid making up $31.92 \%$ of the oil. Palmitic acid $(24.96 \%)$ is the most abundant saturated fatty acid while stearic acid and valeric acid makes up $(7.3 \%)$ and $(1.96 \%)$ respectively. The antimicrobial activity of the oil tested against ten strains of organisms which include: Streptococcus aureus, Escherichia coli, Bacillus subtilis, Pseudomonas aeruginosa, Salmonella typhi, Klebsiella pneumoniae, Candida albicans, Penicillium notatum, Rhijoptius stoloniter and Aspergillus niger showed good activity. The Minimum Inhibition Concentration (MIC) values obtained for the oils ranges from 31.25 to $125 \mathrm{mg} / \mathrm{mL}$ against all the test organisms and within the range $0.125-0.5 \mathrm{mg} / \mathrm{mL}$ for the prepared soap. The physicochemical analysis of the $P$-africana soap was comparable to commercial antiseptic soaps. The result indicated that quality renewable natural antiseptic soaps ccould be obtained from $P_{-}$africana seed oil. The result confirms that soaps made from natural lye (alkaline solution) has the capacity to replace existing commercial antiseptic soaps made of synthetic sodium or potassium hydroxides, antimicrobial agents, artificial preservatives and colourants which partly accounts for environmental pollution, increase in antimicrobial resistance and endocrine disruption. The adoption of this green antiseptic soap synthesis technique utilising underexplored $P$-africana seed oil can help mitigate the negative environmental impact of non-biodegradable synthetic reagents.
\end{abstract}

Keywords: Antimicrobial; Antiseptic; Medicinal soap; Oleic acid; Prosopis africana.

Resumen. Se examinaron las propiedades fisicoquímicas, el perfil de ácidos grasos, la actividad antimicrobiana y el potencial de jabón de la semilla de aceite de Prosopis africana. El jabón antiséptico natural preparado carecía absolutamente de todas las formas de sintéticos tales como agentes alcalinos, antimicrobianos, conservantes, colorantes y fragancias. La semilla tuvo un rendimiento de aceite de $4.98 \%$, mientras que los valores de saponificación, ácido, ácidos grasos libres y yodo fueron $11.60 \pm 0.54 \mathrm{mgKOH} /$ g, $16.96 \pm 0.57 \mathrm{mgKOH} / \mathrm{g}, 14.60 \pm 0.45 \%$ oleico y $145.47 \pm 0.66 \mathrm{I} 2100 \mathrm{~g}^{-1}$ del aceite respectivamente. El resultado de GC-MS del metil éster de ácido graso preparado (FAME) indicó la presencia de ácido oleico (33,67\%), un ácido graso monoinsaturado como el ácido graso más prominente en el aceite, seguido del ácido linoleico (18: 2), Ácido poliinsaturado que constituye el 31,92\% del aceite. El ácido palmítico (24,96\%) es el 
ácido graso saturado más abundante, mientras que el ácido esteárico y el ácido valérico constituyen (7,3\%) y $(1,96 \%)$ respectivamente. La actividad antimicrobiana del aceite analizada contra diez cepas de organismos que incluyen: Streptococcus aureus, Escherichia coli, Bacillus subtilis, Pseudomonas aeruginosa, Salmonella typhi, Klebsiella pneumoniae, Candida albicans, Penicillium notatum, Rhijoptius st. Los valores de Concentración de inhibición mínima (CIM) obtenidos para los aceites varían de 31.25 a $125 \mathrm{mg} / \mathrm{ml}$ frente a todos los organismos de prueba y se encuentran dentro del rango de 0,125 a $0,5 \mathrm{mg} / \mathrm{ml}$ para el jabón preparado. El análisis fisicoquímico del jabón de $P$. africana fue comparable al de los jabones antisépticos comerciales. El resultado indicó que se podrían obtener jabones antisépticos naturales renovables de calidad a partir del aceite de semilla de P. africana. El resultado confirma que los jabones hechos de lejía natural (solución alcalina) tienen la capacidad de reemplazar los jabones antisépticos comerciales existentes hechos de hidróxidos de sodio o potasio sintéticos, agentes antimicrobianos, conservantes artificiales y colorantes que en parte representan la contaminación ambiental, el aumento de la resistencia antimicrobiana y la endocrina. ruptura. La adopción de esta técnica de síntesis de jabón antiséptico verde que utiliza aceite de semilla de $P$. africana poco explorada puede ayudar a mitigar el impacto ambiental negativo de los reactivos sintéticos no biodegradables.

Palabras clave: Antimicrobiano; Antiséptico; jabón medicinal: ácido oléico; Prosopis africana.

\section{Introduction}

Seed oils are important source of bioactive natural compounds, applicable in food and cosmetic industries. Certain oils with specific physicochemical properties are consumed without much processing. Obviously, physicochemical parameters of seed oils are important in the determination of edibility and other industrial applications. For instance, seed oil with high acid value is usually not edible, because the high acidity is attributed to extensive hydrolysis of the oil by lipolytic and oxidizing enzymes [1]. High acid value is also attributed to the induction of the toxicity of oils [2]. Physicochemical characteristics that favours the use of an oil for cooking and other culinary uses include low acid value, low peroxide value, presence of antioxidant compounds and low free fatty acids [3]. These properties determine the overall quality of the oil such as the shell life, wholeness and extent of adulteration. Physicochemical characteristics which makes an oil suitable for industrial applications as in soap production and other cosmetic applications are high acid value and high saponification value. Oils with such physicochemical parameters are usually of low nutritional and food relevance to man.

Microbial infections have become a serious threat to human health worldwide because of the emergence of multi-drug resistant (MDR) microbial strains [4]. Resistance to the existing drugs[5] have led to the search for the new, safe and renewable alternatives [6,7]. Some seed oils are renowned for their antimicrobial properties. Several in vitro studies confirms the effect of seed oils with their major bioactive compounds on pathogenic microbes [8-10]. In recent times, there has been renewed interest on seed oils as sources of novel antimicrobial and antioxidant compounds [11]. The seeds of plant usually contain lipids, fatty acids, amines, proteins and esters which when converted to useful products such as in cosmetics, may be applied for the maintenance, nurturing and rejuvenation of the human skins and hair for improved appearances. In the tropics, many valuable seeds that are oil-rich are allowed to perish each year without anyone paying important attention to them [12]. If the natural resources are properly harnessed and put into good utilisation as in making cosmetic products, it would not only improve individual economic status, but also improve economic situation as the waste are converted to wealth.

The adoption of green principle in the production of cosmetic soaps is certainly an encouraged development. Besides the fact that the green process would free the environment of daily introduction of hazardous chemicals, it would also reduce the effects of pollution, endocrine disruption and other associated diseases in the environment [13]. In addition, the heavy dependence on synthetic chemicals for soap production would drastically reduce if progress is made on improving the source of raw material for soap making [14]. The benefits of a cheap and easily available alkali sources for a cash-strapped developing nation are immense [13]. Efficient designs in the unit operations of the soap making process, as well as in saponification reaction stage, to bring about reasonable substitution of locally derived potassium hydroxide alkali, for imported ones are seriously encouraged [15]. 
The trees of Prosopis africana, of the family "fabaceae", is common in the middle belt zone and Northern parts of Nigeria. It is locally referred to as "kiriya" and "okpehe" in Hausa and Idoma/Tiv languages in Nigeria respectively[16]. Almost all parts of the tree are of important medicinal values; the leaves are used for headache and toothaches as well as other various ailments, the combination of the leaves and bark are used in the treatment of rheumatism, while the bark alone is used as remedies for skin diseases, fever and some eye problems. The roots are a diuretic and are used to treat gonorrhea, tooth and stomach aches, dysentery and bronchitis [17]. Fatty acids and a group of pentacyclic triterpenes were identified as the bioactive responsible for the antibacterial activities. Perilla seed oil [18], poppyseed oil [19], taramira oil [20, 21], tigernut oil [9, 10], have all been shown to be medicinally active across different spectrum of pathogenic microorganisms. There is dearth of information on the chemical composition, physicochemical analysis and antimicrobial activities of the seed oil and soap of Prosopis africana. The Physicochemical activities, fatty acids profile, antimicrobial activities and corresponding cosmetic saponification potential of Prosopis africana seed oil are evaluated and reported for the first time. This study aimed at adopting the principle of green chemistry on underutilized tropical seed to producing antiseptic soaps, free of all synthetic alkali, anti-microbial agents, colourants, fragrance and preservatives but with potential to improve natural beauty, attractiveness and appearance of skin and hair.

\section{Experimental procedure}

Plant materials. The seed of Prosopis africana were collected within Ilorin metropolis, Nigeria. The plant materials were identified at the Herbarium of the Department of Plant Biology, University of Ilorin, Ilorin, Nigeria and voucher specimen numbers UILH/002/472 was obtained. The seeds was dried at ambient temperature, de-shelled, pulverised and kept briefly in a cool dark place for further work.

Solvents and reagents. All reagents and solvents used were analytical grade and where necessary, solvents were re-distilled before use.

Extraction of seed oils. The pulverized $P$. africana seed $(300 \mathrm{~g})$ was subjected to soxhlet extraction using n-hexane at $60{ }^{\circ} \mathrm{C}$ for approximately $3 \mathrm{~h}$. The extract was concentrated via distillation using rotary evaporator.

Physicochemical characterisation of the oils. The physicochemical parameters of the oil were determined using standard procedures with slight modifications where applicable. Odour, colour, and physical state were determined by sensory evaluation [22-24].

\section{Determination of saponification value.}

One $\mathrm{g}$ of the oil was weighed into a conical flask and $25 \mathrm{~mL} 0.5 \mathrm{~N} \mathrm{KOH}$ was added using a pipette. The mixture was warmed in a waterbath for 5 minutes and 3 drops of phenolphthalein indicator was added to it while still warm and then titrated against $0.5 \mathrm{~N} \mathrm{HCl}$ until the pink colour disappeared. The discolouration indicates the end point. A blank (containing no oil) was subjected to the same treatment and results were expressed as $\mathrm{mg} \mathrm{KOHg}{ }^{-1}$.

Saponification value was then calculated using the equation:

$$
\mathrm{SV}=\frac{(B-S) \times M \times 56.1 \mathrm{~g} / \mathrm{mol}}{\text { WEIGHT OF SAMPLE }(g)}
$$

Where $\mathrm{B}=$ blank titre value; $\mathrm{S}=$ sample titre value; molecular weight of $\mathrm{KOH}$ was taken to be $56.1 \mathrm{~g} / \mathrm{mol}$, $\mathrm{M}=$ molarity of $\mathrm{HCl}$

\section{Determination of iodine value}

$0.2 \mathrm{~g}$ of the oil were weighed into $500 \mathrm{~mL}$ conical flask and the oil was dissolved with $15 \mathrm{~mL}$ of dichloromethane. $25 \mathrm{~mL}$ Wiji's solution was added and the flask was stoppered and shakened. The resulting mixture was allowed to stand in the dark for two hours. The flask was removed and $20 \mathrm{~mL}$ of $10 \%$ potassium 
iodide (KI) solution was added followed by an addition of $150 \mathrm{~mL}$ distilled water. The liberated iodine was then titrated with $0.1 \mathrm{M}$ sodium thiosulphate $\left(\mathrm{Na}_{2} \mathrm{~S}_{2} \mathrm{O}_{3}\right)$ shaking it constantly and vigorously until the blueblack color had almost disappearred using starch as indicator. A blank (containing no oil) titration was also carried out.

Results are expressed as $\mathrm{I}_{2} 100 \mathrm{~g}^{-1}$. The iodine value (I.V) was determined by the expression:

$$
\text { I.V. } \frac{V 1-V 2 \times M \times 12.69}{W E I G H T \text { OF SAMPLE }(g)}
$$

where $\mathrm{M}=$ Molarity of sodium thiosulphate; $\mathrm{V} 1$ = titre of sodium thiosulphate used in blank; V2 = titre of sodium thiosulphate used in sample

\section{Determination of acid value}

One $\mathrm{g}$ of the oil was weighed into a flask with $25 \mathrm{~mL}$ of ethanol and 3 drops of phenolphthalein indicator added. The mixture was warmed in a waterbath for 5 minutes and titrated against $0.1 \mathrm{~N} \mathrm{KOH}$ until the pink colours which indicates the end point. A blank was performed alongside. The acid value was expressed as $\mathrm{KOH} \mathrm{g}^{-1}$ and calculated as follows:

$$
\mathrm{AV}=\frac{V 1-V 2 \times N \times 56.1 \mathrm{~g} / \mathrm{mol}}{\text { WEIGHT OF SAMPLE(g) }}=\mathrm{Mg} \text { of } \mathrm{KOH}
$$

where $\mathrm{AV}=$ Acid value; $\mathrm{N}=$ normality of $\mathrm{KOH}$; $\mathrm{V} 1=$ titre for $\mathrm{KOH}$ used in sample; $\mathrm{V} 2=$ titre of $\mathrm{KOH}$ used in the blank

\section{Determination of free fatty acids}

One $\mathrm{g}$ of the oil was boiled with $50 \mathrm{~mL}$ of ethanol and allowed to cool, 2 drops of phenolphthalein indicator was added and titrated against $0.1 \mathrm{~N} \mathrm{KOH}$ until pink colour was obtained. The free fatty acid was calculated using the formula:

$$
\% \text { Free fatty acids }(\% \mathrm{oleic})=\frac{m L O F \mathrm{KOH} \times N \times 56.1 \mathrm{~g} / \mathrm{mol}}{\text { WEIGHT OF SAMPLE }(\mathrm{g})}
$$

where $56.1=$ molecular mass of $\mathrm{KOH} ; \mathrm{V}=$ Average titre value, $\mathrm{N}=$ normality of $\mathrm{KOH}$

\section{Determination of peroxide value}

$0.5 \mathrm{~g}$ of oil was weighed into a conical flask containing $1 \mathrm{~g}$ potassium iodide. The mixture of glacial acetic acid $(13.5 \mathrm{~mL})$ and chloroform $(6.5 \mathrm{~mL})$ was added to it. The conical flask was placed in a waterbath for one minute after which $20 \mathrm{~mL} \mathrm{5 \%}$ potassium iodide and $25 \mathrm{~mL}$ water was added. The whole content was titrated against sodium thiosulphate solution $(0.002 \mathrm{M})$ to colourless using starch as indicator. The results were expressed in meq $\mathrm{Kg}^{-1}$ as peroxide value was calculated using the formula:

$$
\text { Peroxide value }=\frac{V s-V b \times \text { Molarity of titrant } \times 103 \mathrm{~g} / \mathrm{Kg}}{\text { WEIGHT OF SAMPLE }(\mathrm{g})}
$$

where $\mathrm{Vb}=$ titre for blank; $\mathrm{Vs}=$ titre for sample

\section{Preparation of fatty acids methyl ester (FAMEs)}

One $\mathrm{g}$ of the seed oils was weigh into a round bottom flask and $20 \mathrm{~mL} 0.1 \mathrm{M}$ methanolic $\mathrm{KOH}$ was added. The mixtures were refluxed for 1 hour and the supernatant obtained was cooled, transferred to a separating funnel and extracted with n-hexane twice. The oil layer was concentrated in warm waterbath and the oils derived kept in a vial and refrigerated until analysed using GC-MS.

\section{GC-MS Analysis of the FAMEs}

The fatty acid composition of the trans-esterified oil was analysed using an Agilent Technology 7890A gas chromatograph GC-FID, equipped with a fused silica capillary column HP-5MS (30 $\square$ by 0.32 , $0.5 \mu \mathrm{m}$ film thickness) on ultra-pure helium gas and coupled to a mass selective detector (mass spectrometer). 
The fatty acids profile of the FAMEs was identified by comparison of their MS spectral with data obtained from National Institute Standard and Technology (NIST, 2008) database. The relative percentages of the constituent compounds were percentages from the GC peak areas based on the total ion chromatogram (TIC).

\section{Saponification reaction/Mixing ratio}

The seed oil was saponified using hot process since the cold process produced no instant saponification. $5 \mathrm{~mL}$ of the oils were heated to boiling in a beaker and $50 \mathrm{~mL}$ of lye solution was added to the boiling oil with constant stirring. A thick semi-solid mass of saponified product was observed and then allowed to cool and set for some weeks [14,25]. Additives which include $0.3 \mathrm{mg}$ of shea butter (for skin moisturisation) and $0.4 \mathrm{mg}$ of honey (for skin healing and rejuvenation) were added after the saponification to the semi-solid matter and stirred together.

\section{Soap Characterizations}

The saponified product was characterized for its $\mathrm{pH}$, foaming ability, hardness, cleaning effectiveness, solubility and total alkalinity whilst comparing their values with commercial soap samples using standard procedure [26]. Commercial bathing antiseptic soaps which include Dettol and Abuad were used as standard for comparison.

\section{Determination of pH of Soap}

The $\mathrm{pH}$ of soap prepared was determined using a $\mathrm{pH}$ meter ( $827 \mathrm{pH}$ lab model). $1 \mathrm{~g}$ of the soap shavings was weighed and dissolved in deionized water in a $100 \mathrm{~mL}$ volumetric flask. This was then made up to prepare $10 \%$ soap solution. The electrode of the $\mathrm{pH}$ meter was inserted into the solution and the $\mathrm{pH}$ was recorded as described [27].

\section{Foaming ability test}

$0.2 \mathrm{~g}$ of the soap (shavings) was added to a $500 \mathrm{~mL}$ measuring cylinder containing $100 \mathrm{~mL}$ of deionized water. The mixture was shaken vigorously in order to generate foams. After shaking for about 2 minutes, the cylinder was allowed to stand for about 10 minutes. The height of the foam in the solution was measured and recorded thereafter [27].

\section{Solubility tests}

$0.2 \mathrm{~g}$ of each soap was added to a $100 \mathrm{~mL}$ measuring cylinder containing $10 \mathrm{~mL}$ of distilled water. The duration of the dissolution of the soap after continuous shaking was recorded.

\section{Alkalinity test}

The total alkali left after saponification reaction was determined by titration with $\mathrm{HCl} .1 \mathrm{~g}$ of the soap and that of the commercial soaps used as standards were separately dissolved in $100 \mathrm{~mL}$ deionized water and $25 \mathrm{~mL}$ of each soap solution was then titrated against $0.5 \mathrm{M} \mathrm{HCl}$ in triplicates. The volume of acid used was recorded and the total alkalinity calculated using the formula:

$$
\text { Total alkanility }=\left(\frac{\text { Volume of acid used }}{\text { Volume of soap solution }(25 \mathrm{~mL})}\right) \times 100 \%
$$

\section{Test for cleaning effectiveness}

A drop of oil was placed on four separate sheets of filter paper. The filter papers with the oil spot were immersed in a separate test tubes containing soap solution (2 g soap shavings/100 $\mathrm{mL}$ ) each was vigorously shaking for 2 minutes. The filter papers were removed and rinsed with distilled water and the degree of cleanliness in each filter paper observed.

\section{Determination of oils and soap antimicrobial sensitivity}

The antimicrobial sensitivity of $P$. africana oil and the produced soap with other commercial soaps used as standard were examined using selected clinical isolates of bacteria: Streptococcus aureus, Escherichia coli, Bacillus subtilis, Pseudomonas aeruginosa, Salmonella typhi, Klebsiella pneumoniae and fungus: Candida albicans, Pehicillium notatum, Phijoptius stoloniter and Aspergillus niger. $500 \mathrm{mg}$ of the oil was weighed and dissolved in $1 \mathrm{ml}$ of tween-20 to get concentrations of $500 \mathrm{mg} / \mathrm{mL}$. Serial dilution to obtain 
concentrations $1,0.5,0.25,0.125$, and $0.0625 \mathrm{mg} / \mathrm{mL}$ were made. An overnight culture of each organism was made by taken each organism from stock and inoculate into a sterile nutrient broth of $5 \mathrm{~mL}$ each for 18-24 hrs at $37^{\circ} \mathrm{C}$ for bacterial. Pour plate method was used for the bacteria while surface plate methods was used for the fungi. Using a sterile cork borer of $8 \mathrm{~mm}$, the wells were made according to the number of graded concentrations of the sample. All samples were treated in duplicates. The plates were allowed to stay on the bench for $2 \mathrm{hrs}$ to allow pre-diffusion. The plates were incubated uprightly in the incubator for 18-24 hours at $37^{\circ} \mathrm{C}$ for bacterial and $48 \mathrm{hrs}$ at $26-28^{\circ} \mathrm{C}$ for antifungal. The zone of inhibition was measure using a ruler.

\section{Results and discussion}

\section{Physicochemical Analysis of the Seed Oil}

The seed had an oil yield of $4.98 \%$. The $P$. africana oil was light golden yellow in color, liquid at room temperature with palatable flavor. The physicochemical parameters of the oil (Table 1) indicated an acid value $16.96 \pm 0.57 \mathrm{mgKOH} / \mathrm{g}$ which is above the value $(4 \mathrm{mgKOH} / \mathrm{g})$ recommended for edible oil by $\mathrm{WHO} / \mathrm{FAO}$. The value indicated that the oil would be applicable for non-edible purposes as in soap-making. The low peroxide value, $6.81 \pm 0.44 \mathrm{meqKg}^{-1}$, could be as a result of the presence of phytochemicals that acts as natural antioxidants. The oil has a low percentage $(14.60 \pm 0.45)$ of free fatty acid which is indicative of the freshness of the oil. The oil has a moderate saponification value $(11.6 \pm 0.54 \mathrm{mgKOH} / \mathrm{g})$ and high iodine value $(145.47 \pm 0.66)$. The high iodine value which indicates the degree of unsaturation reveals that the oil is highly unsaturated. This was further confirmed by the GC-MS analysis (Table 2) which shows a total unsaturation of $65.69 \%$ for the oil. The high degree of unsaturation of the oil partly confirmed the physical state of the oil as liquid at ambient temperature.

Table 1. Physicochemical Analysis of the Seed Oil

\begin{tabular}{|l|l|l|}
\hline Parameter & Prosopis africana & WHO/FAO (Edible Oil) \\
\hline \% Yield & 4.98 & NS \\
\hline Saponification value $(\mathrm{mg} \mathrm{KOH} / \mathrm{g})$ & $11.6 \pm 0.54$ & $181.4 \pm 2.60$ \\
\hline Acid value $(\mathrm{mg} \mathrm{KOH} / \mathrm{g})$ & $16.96 \pm 0.57$ & 4 \\
\hline \% Free fatty acid & $14.60 \pm 0.45$ & $5.78-7.28$ \\
\hline Peroxide value $\left(\mathrm{meq} \mathrm{Kg}^{-1}\right)$ & $6.18 \pm 0.04$ & 10 \\
\hline Iodine value $\left(\mathrm{I}_{2} 100 \mathrm{~g}^{-1}\right.$ of oil) & $145.47 \pm 0.66$ & $80-108$ \\
\hline Colour & Yellow & NS \\
\hline Physical state at ambient temperature $\left(25^{\circ} \mathrm{C}\right)$ & Liquid & NS \\
\hline
\end{tabular}

- $\quad$ values are average of triplicates determinations; NS - None Specified

\section{Fatty Acids Composition of Extracted Oils}

The fatty composition of the seed oil is shown in Table 2. Oleic acid (33.67\%) a monounsaturated fatty acid is the most prominent fatty acid in the oil, followed linoleic acid (18:2), an unsaturated fatty acid making up $31.92 \%$ of the total oil yield. Palmitic acid, a saturated fatty acid accounts for $24.96 \%$ of the oil.. Stearic acid and valeric acid makes up (7.3\%) and (1.96\%) respectively in the oil. 
Table 2. Fatty Acids Composition of the Oils

\begin{tabular}{|l|l|l|l|l|}
\hline Peak no. & Retention Time (min) & Fatty acids & Saturation & $\begin{array}{l}\text { \% } \\
\text { Composition }\end{array}$ \\
\hline 1 & 12.55 & Valeric acid & $5: 0$ & 1.96 \\
\hline 2 & 13.32 & Palmitic acid & $16: 0$ & 24.97 \\
\hline 3 & 13.81 & Linoleic acid & $18: 2$ & 31.92 \\
\hline 4 & 13.93 & Stearic acid & $18: 0$ & 33.67 \\
\hline 5 & 14.13 & Total Saturate & & 7.38 \\
\hline & & Monounsaturate & & 34.31 \\
\hline & & Polyunsaturate & & 33.67 \\
\hline
\end{tabular}

- $\quad$ RT indicates retention time on the column in minutes.

\section{Antimicrobial Activity of the Oil}

Table 3 shows growth inhibition of the test organisms against the seed oil. Inhibition was observed at concentration ranging from 31.25 to $500 \mathrm{mg} / \mathrm{L}$. The MIC values ranges from 31.25 to $125 \mathrm{mg} / \mathrm{L}$ against all the test organisms. Appreciable antibacterial activities were recorded against $S$. typhi $(19.0 \pm 1.41)$, E. coli $(19.0 \pm 1.41) \mathrm{mm}$ and $(17.0 \pm 1.41) \mathrm{mm}$ against $S$. aureus. The oil shows improved fungal inhibitory effect for both $C$. albicans and $R$. stoloniter with $(15.0 \pm 1.41) \mathrm{mm}$ diameter zone of inhibition. Erythromycin (positive control) shows an average antibacterial zone of inhibition of $(40 \pm 1.41) \mathrm{mm}$ while fluconazole had an average antifungal effects of $(30 \pm 1.41) \mathrm{mm}$ at concentrations of $0.25 \mathrm{mg} / \mathrm{mL}$. The antimicrobial result is comparable with the work of Kolapo et al., (2009) [28], who reported similar activities for ethanolic and aqueous extracts of the plant.

Table 3. Inhibitory effect of Prosopis africana Seed Oil against pathogens.

\begin{tabular}{|l|l|l|l|l|l|l|l|}
\hline Pathogens & \multicolumn{7}{|c|}{ Concentrations (mg/mL) } \\
\hline & $\mathbf{5 0 0}$ & $\mathbf{2 5 0}$ & $\mathbf{1 2 5}$ & $\mathbf{6 2 . 5}$ & $\mathbf{3 1 . 2 5}$ & $\mathbf{1 5 . 6 3}$ & MIC \\
\hline & & & & & & & \\
\hline S. aureus & $17 \pm 1.41$ & $14 \pm 0.00$ & $12 \pm 0.00$ & $10 \pm 0.00$ & - & - & 62.50 \\
\hline B. subtilis & $16 \pm 0.00$ & $14 \pm 0.00$ & $12 \pm 0.00$ & $10 \pm 0.00$ & - & - & 62.50 \\
\hline E. coli & $19 \pm 1.41$ & $17 \pm 1.41$ & $14 \pm 0.00$ & $12 \pm 0.00$ & $10 \pm 0.00$ & - & 31.25 \\
\hline $\begin{array}{l}P . \\
\text { aeruginosa }\end{array}$ & $13 \pm 1.41$ & $10 \pm 0.00$ & - & - & - & - & 250.00 \\
\hline S. typhi & $19 \pm 1.41$ & $17 \pm 1.41$ & $15 \pm 1.41$ & $13 \pm 1.41$ & $10 \pm 0.00$ & - & 31.25 \\
\hline $\begin{array}{l}\text { K. } \\
\text { pnemonae }\end{array}$ & $13 \pm 1.41$ & $10 \pm 0.00$ & - & - & - & - & 250.00 \\
\hline R. stoloniter & $15 \pm 1.41$ & $13 \pm 1.41$ & $10 \pm 0.00$ & - & & - & - \\
\hline P. notatam & $13 \pm 1.41$ & $10 \pm 0.00$ & - & - & - & - & 125.00 \\
\hline C. albicans & $15 \pm 1.41$ & $13 \pm 1.41$ & $10 \pm 0.00$ & - & - & - & 250.00 \\
\hline A. Niger & $16 \pm 0.00$ & $14 \pm 0.00$ & $12 \pm 0.00$ & $10 \pm 0.00$ & - & - & 125.00 \\
\hline
\end{tabular}

- means no activity, values are average of duplicates samples 


\section{Mixing ratio of the oil/fat used for the saponification}

The mixing ratio of oil for the saponification, colour, and washing efficiency of the soaps are shown in Table 4. The soap made from P. africana deep yellow. Honey, shear butter oil was added for rejuvenation and penetration into the skin respectively. The soap shows washing efficiency that is comparable to commercial soaps (Dettol and Abuad) used as standards.

Table 4. Mixing ratio of the oil/fat used for the saponification

\begin{tabular}{|l|l|l|l|l|}
\hline $\begin{array}{l}\text { Soap } \\
\text { Formulations }\end{array}$ & $\begin{array}{l}\text { Oil/Fat and Addictive } \\
\text { mixing ratio }\end{array}$ & Mixing ratios & Soap Colour & $\begin{array}{l}\text { Washing } \\
\text { efficiency* }\end{array}$ \\
\hline $\begin{array}{l}\text { Prosopis africana } \\
\text { Soap }\end{array}$ & Oil+honey+shear butter & $0.95: 0.025: 0.025$ & Deep brown & Very good \\
\hline Dettol & - & - & White & Very good \\
\hline Abuad & - & - & Green & Very good \\
\hline
\end{tabular}

*Sensory evaluation

\section{Physicochemical Characterization of the Prepared Soaps}

The physicochemical analysis of the prepared soap as well as the commercial soaps (Dettol) used as standard are reported (Table 5). The $\mathrm{pH}$ value of the soap was determined immediately after caking of the soap and one month after curing (after saponification). The $\mathrm{pH}$ of all soap were within the acceptable range of 8.4-8.6 recommended for commercial soap and also in agreement with literature [25, 29]. Soap made from $P$. africana seed oil shows a foaming height and solubility comparable to the commercial soaps used as standard (Figures 2 and 3). This result indicate that high quality natural antiseptic soap could be made from Prosopis africana seed oil. The result further confirms that soaps made from natural lye has the capacity to replace existing synthetic $\mathrm{NaOH}$ and $\mathrm{KOH}$. The use of synthetic preservatives, colourants, antimicrobial agent which may account for the non-biodegradability of the commercial soaps, hence polluting the environment, is a problem that natural antiseptic soap obtained from $P$. africana can remedy as all the ingredients used in its production are from natural renewable and biodegradable.

Table 5. Physicochemical characterization of the soaps

\begin{tabular}{|l|l|l|l|}
\hline Soap sample & Prosopis africana & Dettol & Abuad \\
\hline $\mathrm{pH}_{\text {before curing* }}^{*}$ & $10.05 \pm 0.07$ & $9.85 \pm 0.07$ & $9.65 \pm 0.07$ \\
\hline $\mathrm{pH}$ after curing (5 weeks) ${ }^{*}$ & $8.5 \pm 0.00$ & $8.50 \pm 0.07$ & $8.6 \pm 0.00$ \\
\hline Foam height (cm)* & $2.50 \pm 0.42$ & $2.00 \pm 0.28$ & $2.60 \pm 0.28$ \\
\hline Solubility (sec)* & $393 \pm 9.60$ & $786 \pm 8.20$ & $668 \pm 5.4$ \\
\hline Total Alkalinity \% & 0.40 & 0.40 & 0.80 \\
\hline Texture** & Very hard & Hard & Very Hard \\
\hline
\end{tabular}

*Data were obtained in triplicate

**Sensory evaluation 


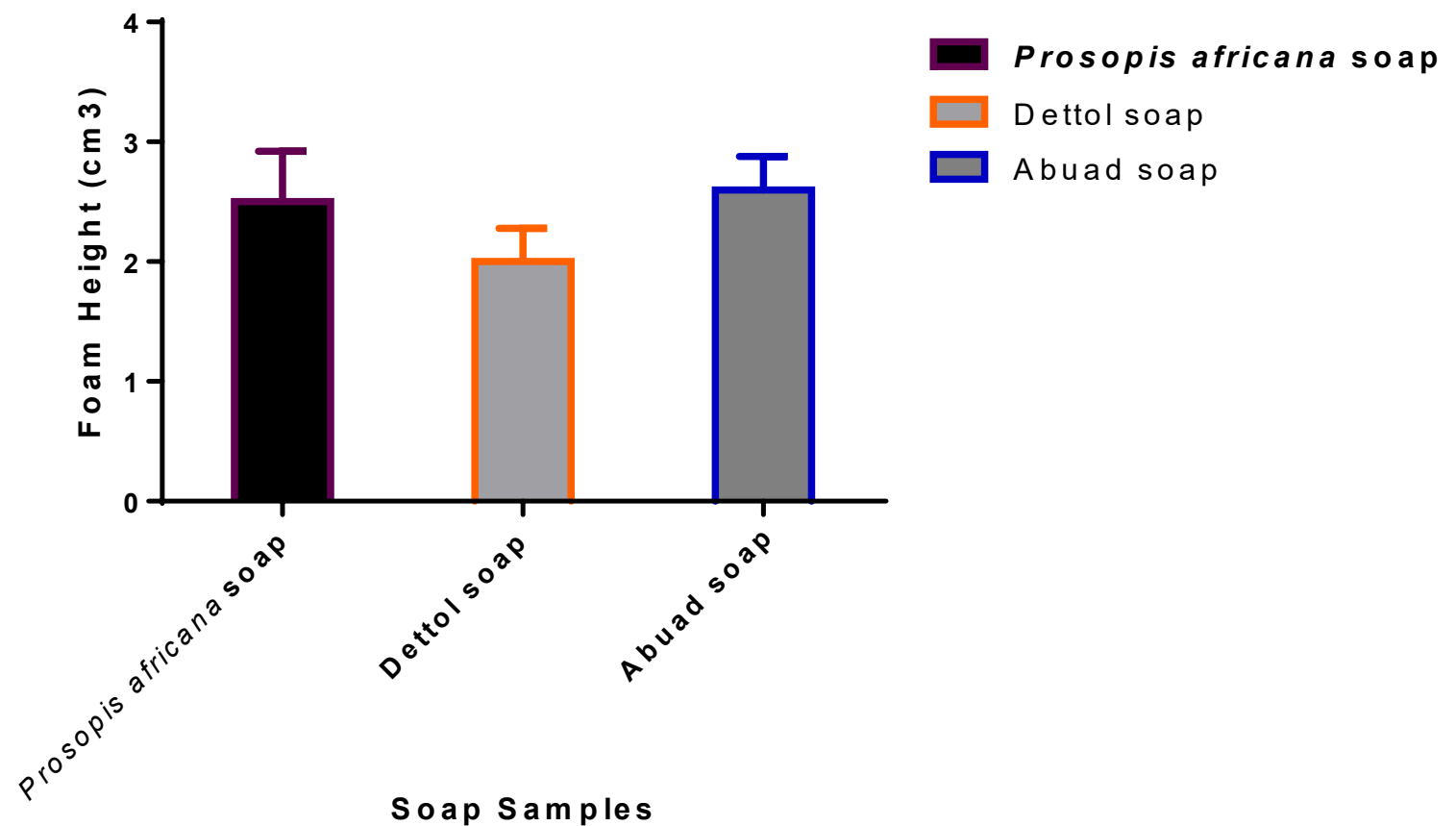

Fig. 2. Foaming ability of the soaps

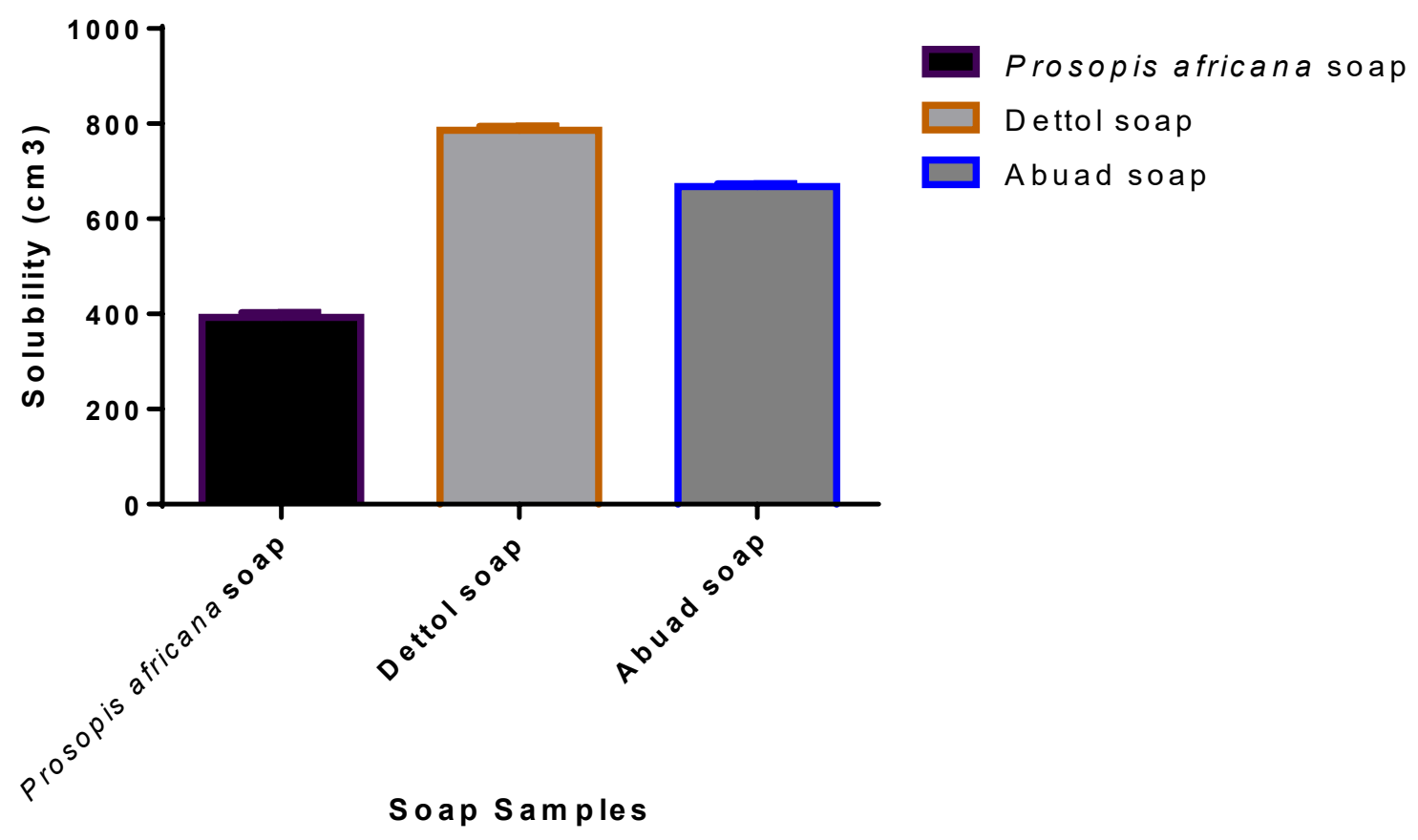

Fig. 3. Solubility Test of the soaps 


\section{Antimicrobial activity of the Soaps}

The antimicrobial activities of the oil (Table 6) are retained in the soap produced. The diameter zone of inhibition was dose dependent measured relative to that of the commercial soap (dettol) used as control. Highest inhibition zone of $61.8 \% \pm 2.3$ were observed for bacterial and $71.4 \% \pm 2.3$ against fungi. The result implies the produce soap is effective against both bacterial and fungi. The result adds credence to the application of $P$. africana seed oil and other bioactive seed oil in antiseptic soap making. The presence of natural antimicrobial agents in the seed oil makes it more applicable for management of skin infections without the need for synthetic ones. The comparable antimicrobial activities of the oil and soap of seed oil from $P$. africana can be attributed to synergistic action of different natural antimicrobial component which makes natural soaps better suited in fighting antimicrobial infections compare to commercial soaps whose active antimicrobial agents such as synthetic triclosan are known to induce antimicrobial resistance beside causing other biological defects like endocrine disruption [30, 31]. The antimicrobial activities of $P$. africana is comparable to that of dettol soap whose antiseptic agents include a broad spectrum synthetic antibiotic, chloroxylenol. Chloroxylenol is not eco-friendly as it is known to be toxic to fresh water invertebrates and fish and induce irritation and allergic reaction in human [26]. Natural antiseptic soap from the seed oil of $P$. africana with the inclusion of antibiotic agents of plant origin can compete favourably and replace the commercial synthetic options.

Table 6. Inhibitory effect of Prosopis africana soap against pathogens

\begin{tabular}{|l|l|l|l|l|l|l|l|}
\hline Pathogens & \multicolumn{7}{|c|}{ Concentrations (mg/mL) } \\
\hline & $\mathbf{2 . 0 0}$ & $\mathbf{1 . 0 0}$ & $\mathbf{0 . 5 0}$ & $\mathbf{0 . 2 5}$ & $\mathbf{0 . 1 2 5}$ & $\mathbf{0 . 0 6 2 5}$ & MIC \\
\hline & \multicolumn{7}{|c|}{ Zone of inhibition (\%) } \\
\hline S. aureus & $58.8 \pm 0.0$ & $56.7 \pm 2.3$ & $53.8 \pm 0.0$ & $50.0 \pm 2.3$ & - & - & 0.25 \\
\hline B. subtilis & $53.1 \pm 2.3$ & $46.7 \pm 0.0$ & $46.2 \pm 2.3$ & $47.6 \pm 0.0$ & - & - & 0.25 \\
\hline E. coli & $50.0 \pm 2.3$ & $46.7 \pm 0.0$ & $44.4 \pm 0.0$ & $41.7 \pm 0.0$ & - & - & 0.25 \\
\hline P. aeruginosa & $50.0 \pm 2.3$ & $46.7 \pm 0.0$ & $46.2 \pm 0.0$ & $43.4 \pm 0.0$ & - & - & 0.25 \\
\hline S. typhi & $61.8 \pm 2.3$ & $56.3 \pm 0.0$ & $51.7 \pm 1.4$ & $50.0 \pm 2.3$ & $66.7 \pm 0.0$ & - & 0.125 \\
\hline K. pnemonae & $58.8 \pm 0.0$ & $58.1 \pm 0.0$ & $50.0 \pm 0.0$ & $48.0 \pm 0.0$ & $71.4 \pm 0.0$ & - & 0.125 \\
\hline R. stoloniter & $62.5 \pm 2.3$ & $60 \pm 0.0$ & $55.6 \pm 0.0$ & - & - & - & 0.50 \\
\hline P. notatam & $62.5 \pm 2.3$ & $65.0 \pm 2.3$ & $58.8 \pm 0.0$ & - & - & - & 0.50 \\
\hline C. albicans & $70.8 \pm 2.3$ & $70 \pm 2.3$ & $70.6 \pm 2.3$ & $71.4 \pm 2.3$ & - & - & 0.25 \\
\hline A. Niger & $60.0 \pm 2.3$ & $59.1 \pm 2.3$ & $55.6 \pm 0.0$ & - & - & - & 0.50 \\
\hline
\end{tabular}

- means no activity, values are average of duplicates samples

\section{Conclusion}

The physicochemical properties and fatty acid profile of Prosopis africana, its potential in combating skin infectious organisms when applied in specialized soap was investigated. The physicochemical analysis indicated that the oil would be very suitable for industrial purpose. The physicochemical properties, antioxidant and broad spectrum anti-microbial properties of the oil and prepared soap makes the oil highly recommended for the production of special natural antiseptic soap for skin cleansing and maintenance. The fatty acid profile further shows that the oil can be exploited as a source of polyunsaturated fatty acid as linoleic (18:2) and oleic (18:1) fatty acids. The soap made from the oil is free from every form of synthetic chemicals. This work demonstrated that soap made from natural lye has the capacity to replace existing commercial synthetic alkali, preservatives, colourants and antimicrobial agents which are known to cause environmental impedance, endocrine disruption and microbial resistance. The detail scientific data regarding the physicochemical, antimicrobial and soap potential of the seed oil of $P$. africana exhibited in this work would be very relevant for the development and commercialization of the underexplored seed oil into cosmetics and other allied products. 


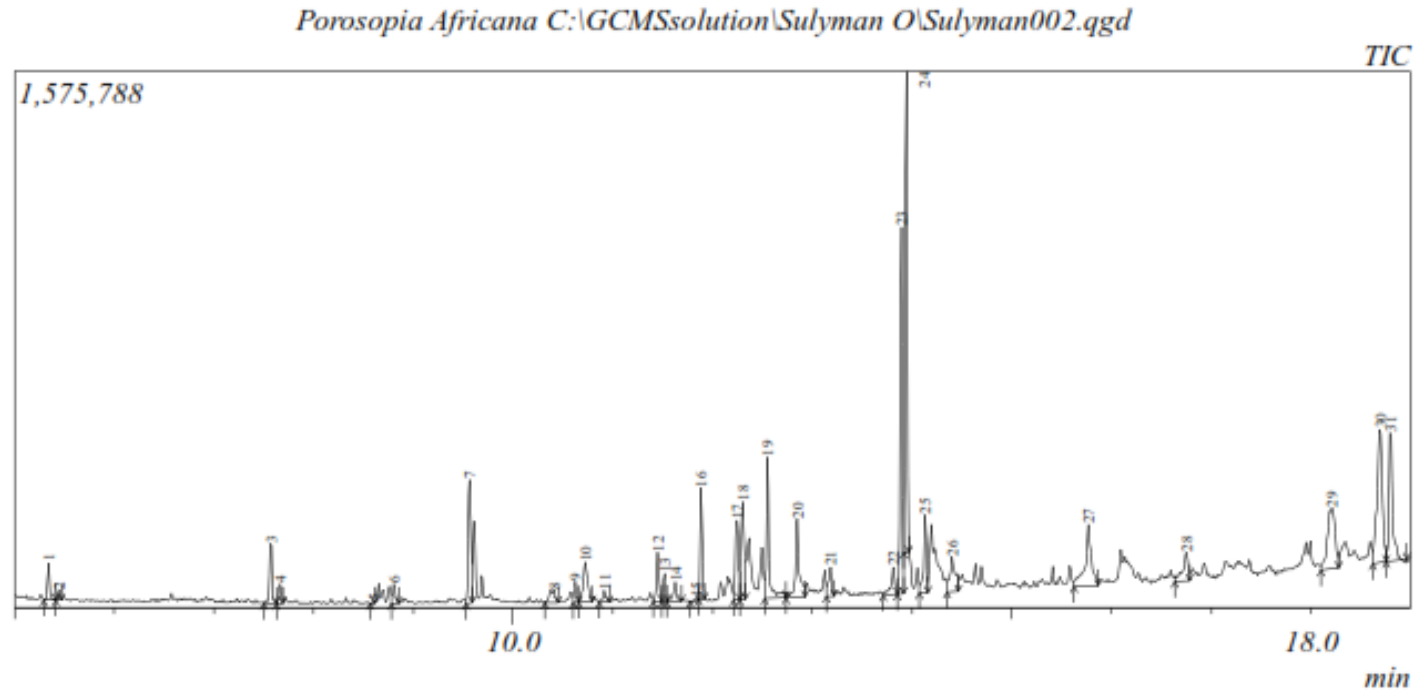

Fig. 1. GC-MS Chromatogram of esterified $P$. africana seed oil

\section{Acknowledgements}

This work was supported by TWAS research grant, 15-244 RG/CHE/AF/AC_G - FR3240287031.

\section{References}

1. Fakhri, N.; Qadir, H. Journal of Environmental Science and Engineering, 2011, 5.

2. Aremu, M.; Olaofe, O.; Akintayo, E. J. Appl. Sci, 2006, 6, 1900-1903.

3. Aremu, M.; Ibrahim, H.; Bamidele, T. Chem. Proc. Eng. Res., 2015,7, 36-52.

4. Tabassum, W.; Kullu, A. R.; Sinha, M. The bioscan, 2013, 8, 665-669.

5. Rios, J.; Recio, M.; Villar, A. Journal of ethnopharmacology, 1988, 23, 127-149.

6. Van Hal, S.; Paterson, D. L.; Gosbell, I. B. European journal of clinical microbiology \& infectious diseases, 2011, 30, 603-610.

7. Sass, P.; Berscheid, A.; Jansen, A.; Oedenkoven, M.; Szekat, C.; Strittmatter, A.; Gottschalk, G. Journal of bacteriology, 2012,194, 2107-2108.

8. Burt, S. International journal of food microbiology, 2004, 94, 223-253.

9. Abano, E.; Amoah, K. Asian Journal of Agricultural Research, 2011, 5, 56-66.

10. Arafat, S. M.; Gaafar, A. M.; Basuny, A. M.; Nassef, S. L. World Applied Sciences Journal, 2009, 7 , 151-156.

11. Jarret, R. L.; Wang, M. L.; Levy, I. J. Journal of agricultural and food chemistry, 2011, 59, 4019-4024.

12. Atolani, O.; Adeniyi, O.; Kayode, O. O.; Adeosun, C. B. Journal of Applied Pharmaceutical Science, 2015, 5, 024-028.

13. Undiandeye, J. A.; Chior, T. J.; Mohammed, A.; Offurum, J. C. AU Journal of Technology, $2014,17$.

14. Ogunsuyi, H.; Akinnawo, C. Journal of Applied Sciences and Environmental Management, 2012,16.

15. Onyegbado, C.; Iyagba, E.; Offor, O. Journal of Applied Sciences and Environmental Management, 2002, 6, 73-77.

16. Agboola, D. Economic Botany, 2004, 58, S34-S42.

17. Ajiboye, A. Ph. D. Thesis. Department of Biological Sciences, Federal University of Agriculture, Abeokuta, Nigeria, 2009. 
18. Kwon, K. H.; Im Kim, K.; Jun, W. J.; Shin, D. H.; Cho, H. Y.; Hong, B. S. Biological and Pharmaceutical Bulletin, 2002, 25, 367-371.

19. Huda, S. N.; Grantham-McGregor, S. M.; Tomkins, A. The Journal of nutrition, 2001,131, $72-77$.

20. Miyazawa, M.; Nishiguchi, T.; Yamafuji, C. Flavour and fragrance journal, 2005, 20, 158-160.

21. Lazzeri, L.; Errani, M.; Leoni, O.; Venturi, G. Industrial Crops and Products, 2004, 20, 67-73.

22. Van Gerpen, J. Fuel processing technology, 2005, 86, 1097-1107.

23. Ibeto, C. N.; Okoye, C. O. B.; Ofoefule, A. U. ISRN Renewable Energy, 2012.

24. Ratnayake, W. N.; Hansen, S. L.; Kennedy, M. P. Journal of the American oil chemists' society, 2006, $83,475-488$.

25. Warra, A. African Journal of Pure and Applied Chemistry, 2013, 7, 139-145.

26. Ameh, A.; Muhammad, J.; Audu, H. African Journal of Biotechnology, 2013, 12.

27. Atolani, O.; Olabiyi, E. T.; Issa, A. A.; Azeez, H. T.; Onoja, E. G.; Ibrahim, S. O.; Zubair, M. F. Sustainable Chemistry and Pharmacy, 2016, 4, 32-39.

28. Kolapo, A.; Okunade, M.; Adejumobi, J.; Ogundiya, M. World Journal of Agricultural Sciences, 2009, 5, 90-93.

29. Vivian, O. P.; Nathan, O.; Osano, A.; Mesopirr, L.; Omwoyo, W. N. Open Journal of Applied Sciences, 2014, 4, 433.

30. Poole, K. Journal of Applied Microbiology, 2002, 92, 55S-64S.

31. Chuanchuen, R.; Beinlich, K.; Hoang, T. T.; Becher, A.; Karkhoff-Schweizer, R. R.; Schweizer, H. P. Antimicrobial agents and chemotherapy, 2001, 45, 428-432. 